\title{
May Monetary Transmission Lags Have a Role in Missing Inflation Targets in Turkey? Cointegration Tests with Structural Breaks and Structural VAR Analysis
}

\author{
Umit Bulut $^{1}$ \\ ${ }^{1}$ Department of Economics, Ahi Evran University, Kirsehir, Turkey \\ Correspondence: Umit Bulut, Department of Economics, Ahi Evran University, Kirsehir, 40100, Turkey. Tel: \\ 90-386-280-4920. E-mail: ubulut@ahievran.edu.tr
}

Received: February 16, 2016

Accepted: March 1, 2016

Online Published: March 25, 2016

doi:10.5539/ijef.v8n4p93

URL: http://dx.doi.org/10.5539/ijef.v8n4p93

\begin{abstract}
This paper aims at estimating the monetary transmission lag in Turkey by utilizing quarterly data from 2006:1 to 2015:4. To this end, the paper, first, follows unit root tests and cointegration tests. Then, the paper employs structural vector autoregressive (SVAR) analysis. SVAR analysis explores that a positive one-unit standard deviation shock to real interest rate causes inflation to decrease in the eighth period and the decrease in inflation prolongs up to the tenth period. Therefore, SVAR analysis yields that the monetary transmission lag is two and a half years in Turkey. Based on its own findings and those of a previously produced paper which yields that the CBRT considers 12-month ahead expected inflation rate while it is steering interest rates, the paper thus argues that monetary transmission lags may have a role in missing inflation targets in Turkey along with some other factors. In conclusion, the paper argues that the CBRT should pay attention to 24-month ahead or 30-month ahead expected inflation rates instead of 12-month ahead expected inflation rate to achieve or run-up to inflation targets.
\end{abstract}

Keywords: the Central Bank of the Republic of Turkey, monetary transmission lag, real interest rate, inflation, structural vector autoregressive analysis

\section{Introduction}

Since the seminal papers by Friedman $(1961,1968,1972)$, a widely accepted argument in the monetary economics literature about the transmission mechanism of monetary policy has been that monetary policy actions affect an economy only after a lag which is both long and variable. These lags are inside lag (the reaction of a central bank to an undesired event in the economy), intermediate lag (the reaction of banks and financial markets to this adjustment of the central bank), and outside lag (the reaction of investment and saving decisions of non-financial institutions) (Bofinger et al., 2001; Mishkin, 2012). Among these lags, it is accepted that outside lag is particularly long and variable (Mishkin, 2012).

After monetary targeting and exchange rate targeting experiences, the policy instrument which many central banks basically adjust is short-term/overnight interest rate at the present time (Goodhart, 2001). In other words, many central banks conduct monetary policy by steering short-term interest rate instead of trying to achieve the growth target in monetary base or money supply (Bulut, 2016). Within this scope, the reaction function of a central bank presents how the central bank adjusts short-term interest rate in respect of economic events (Judd \& Rudebusch, 1998; Bulut, 2016). Given the lagged effect of monetary policy on inflation, central banks focus on expected inflation rather than actual inflation rates. Thereby central banks adjust short-term interest rate with regard to changes in expected inflation. In monetary economics literature, the equation that shows how a central bank adjusts short-term interest rate with regard to changes in expected inflation is denominated as a forward-looking reaction function (Clarida et al., 1998, 2000).

When one examines the empirical literature on the reaction function of the Central Bank of the Republic of Turkey (CBRT), he/she will observe that papers that estimate a forward-looking reaction function for the CBRT examine whether the CBRT reacts to changes in the difference between 12-month ahead expected inflation rate and inflation target (see e.g., Berument \& Malatyali, 2000; Berument \& Tasci, 2004; Yazgan \& Yilmazkuday, 2007). Hence, these paper implicitly assume that the effect of monetary policy on inflation is arisen in 12 month 
in Turkey and the CBRT steers short-term interest rate considering this lagged effect. A recently produced paper by Bulut (2016) investigates whether the CBRT considers 12-month ahead expected inflation or 24-month ahead expected inflation and yields that the CBRT focuses on 12-month ahead expected inflation rate while steering short-term interest rate. Thus the paper argues that the CBRT may have estimated the monetary transmission lag for inflation in Turkey is one year. The paper denotes that the CBRT has adopted inflation targeting strategy since 2006, and during the period 2006-2014, the CBRT achieved inflation targets only in 2009 and 2010. Then, the paper asks a considerable question as follows: "Could the actual lag in the monetary transmission mechanism be longer than the estimation of the CBRT"?

This paper tries to find an answer to this question by estimating the monetary transmission lag in Turkey. In other words, this paper, using quarterly data covering the period 2006:1-2015:4, examines when the overall effect of monetary policy on inflation is shown up in Turkey after a monetary policy action. This paper employs cointegration tests with structural breaks and structural vector autoregressive (SVAR) models to estimate the monetary transmission lag in Turkey.

This paper contributes to literature in several ways. First, this paper employs cointegration tests with structural breaks and SVAR analysis. Because, cointegration tests without structural breaks may give misleading findings about the cointegration relationship between variables and performing SVAR analysis instead of conventional VAR analysis may present more reliable findings as will hereinafter be explained. Second, there are only a few papers estimating the monetary transmission lag in Turkey by using short-term interest rate and inflation data (Cicek, 2005; Guloglu \& Orhan, 2008; Erdogan \& Besballi, 2009; Ornek, 2009; Artar, 2011). Third, the data sets all these papers use include observations in 1990s and 2000s. However, as Brooks (2007) and Basci et al. (2008) remark, the Turkish economy has experienced some structural changes since the 2001 crisis, such as the introduction of a flexible exchange rate regime with the new central bank law, the recapitalization of the banking sector, and the adoption of inflation targeting strategy. Moreover, although the CBRT has used short-term interest rate to achieve inflation targets since 2002, short-term interest rate has been the benchmark for monetary policy of the CBRT since 2006 (Note 1). As the data set that this paper uses begin with the year 2006, this paper will present more reliable findings about the monetary transmission lag in Turkey.

The rest of the paper is organized as follows: Section 2 gives data. Section 3 presents methodology. Section 4 reports estimation results. Section 5 concludes the paper with a summary of findings and some policy implications.

\section{Data}

This paper follows time series data for Turkey. The data are quarterly and cover the period 2006:1-2015:4. The variables are inflation rate (annual growth rate of consumer price index) and real-short term interest rate (the difference between TRlibor and 12-month ahead annual expected inflation rate). I use real interest rate instead of nominal interest rate since consumption, investment, and saving decisions of economic actors depend on real interest rate. While the data for inflation rate are extracted from the CBRT (2016), the data for real short-term interest rate are obtained from the CBRT (2016) and the Banks Association of Turkey (2016). INF denotes inflation rate while INT stands for real short-term interest rate in the paper.

Table 1. Descriptive statistics and correlation matrix for INF and INT

\begin{tabular}{lcc}
\hline & INF & INT \\
\cline { 2 - 3 } Descriptive Statistics & & \\
Mean & 8.30 & 4.27 \\
Median & 8.33 & 3.51 \\
Maximum & 11.65 & 11.97 \\
Minimum & 4.34 & -1.10 \\
Std. deviation & 1.66 & 4.35 \\
Observations & 40 & 40 \\
\hline Correlation Matrix & & \\
INF & 0.51 & 0.51 \\
INT & & \\
\hline
\end{tabular}




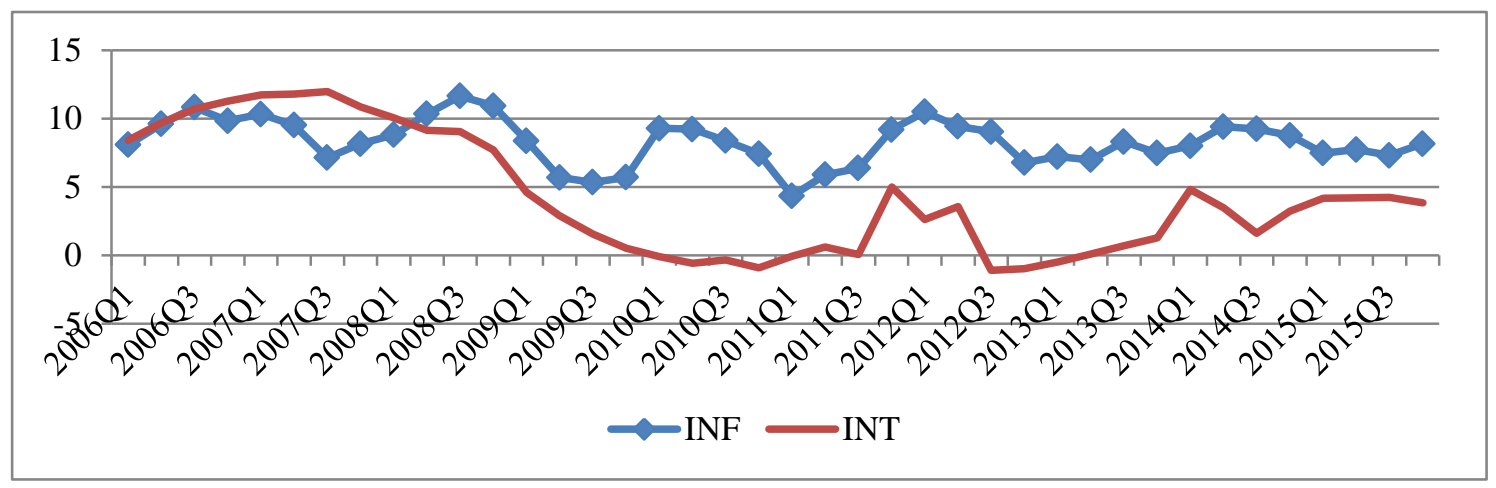

Figure 1. The trends of INF and INT $(\%)$

Descriptive statistics and correlation matrix are presented in Table 1. One notes that mean, median, and minimum of INF are greater than those of INT while maximum and standard deviation of INT are greater than those of INF. One may notice, as well, that there is a positive correlation between INF and INT. Figure 1 depicts graphical observations of the variables. As seen, INF fluctuates around $8 \%$. Besides, while there is a sharp decline in INT due to the global crisis, INT exhibits irregular movements in the aftermath of the global crisis. Graphical observations are of course are to provide one with some initial and/or preliminary inspection. However, beyond graphical analyses, one may need to consider, as well, some statistical methodologies to observe the relationships between variables.

\section{Methodology}

\subsection{Unit Root Tests}

Determining the order of integration of variables is the first step in time series analyses since one may experience spurious regression problem when conventional ordinary least squares (OLS) is employed for the analyses.

Unit root tests developed by Dickey and Fuller (1981, hereafter ADF) and Phillips and Perron (1988, hereafter PP) are commonly performed in econometrics literature. The main shortcoming of ADF and PP tests is that they do not take into account possible structural breaks in series. However, researchers should consider the possibility of structural breaks in series to estimate the parameters unbiasedly and efficiently.

Narayan and Popp (2010) propound a unit root test with two structural breaks endogenously determined. They propose two models allowing for two structural breaks. The first model, namely M1, allows for two structural breaks in intercept while the second model, namely M2, allows for two structural breaks in intercept as well as trend.

The data-generating process of a time series $y_{t}=d_{t}+u_{t}$ that Narayan and Popp (2010) define has two components, a deterministic component $\left(d_{t}\right)$ and a stochastic component $\left(u_{t}\right)$ where $u_{t}$ exhibits an AR (1) process. Models are demonstrated as follows:

$$
\begin{gathered}
d_{t}^{\mathrm{M} 1}=\alpha+\beta \mathrm{t}+\Psi^{*}(\mathrm{~L})\left(\theta_{1} \mathrm{DU}_{1, \mathrm{t}}^{\prime}+\theta_{2} \mathrm{DU}_{2, \mathrm{t}}^{\prime}\right) \\
\mathrm{d}_{\mathrm{t}}^{\mathrm{M} 2}=\alpha+\beta \mathrm{t}+\Psi^{*}(\mathrm{~L})\left(\theta_{1} \mathrm{DU}_{1, \mathrm{t}}^{\prime}+\theta_{2} \mathrm{DU}_{2, \mathrm{t}}^{\prime}+\gamma_{1} \mathrm{DT}_{1, \mathrm{t}}^{\prime}+\gamma_{2} \mathrm{DT}_{2, \mathrm{t}}^{\prime}\right)
\end{gathered}
$$

where $\mathrm{DU}_{\mathrm{i}, \mathrm{t}}^{\prime}=1\left(\mathrm{t}>\mathrm{T}_{\mathrm{B}, \mathrm{i}}^{\prime}\right), \mathrm{DT}_{\mathrm{i}, \mathrm{t}}^{\prime}=1\left(\mathrm{t}>\mathrm{T}_{\mathrm{B}, \mathrm{i}}^{\prime}\right)\left(\mathrm{t}-\mathrm{T}_{\mathrm{B}, \mathrm{i}}^{\prime}\right), \mathrm{i}=1,2$.

Here, $\mathrm{T}_{\mathrm{B}, \mathrm{i}}^{\prime}, \mathrm{i}=1,2$ denotes the break dates. The parameters $\theta_{\mathrm{i}}$ and $\gamma_{\mathrm{i}}$ stand for the magnitude of the intercept and trend breaks, respectively. Narayan and Popp (2010) remark that the inclusion of $\Psi^{*}(\mathrm{~L})$ allows breaks to happen slowly over time.

The test regressions are the reduced forms of the corresponding structural model. They are showed as follows:

$$
\begin{gathered}
\mathrm{y}_{\mathrm{t}}^{\mathrm{M} 1}=\rho \mathrm{y}_{\mathrm{t}-1}+\alpha_{1}+\beta^{*} \mathrm{t}+\theta_{1} \mathrm{D}\left(\mathrm{T}_{\mathrm{B}}^{\prime}\right)_{1, \mathrm{t}} \\
+\theta_{2} \mathrm{D}\left(\mathrm{T}_{\mathrm{B}}^{\prime}\right)_{2, \mathrm{t}}+\delta_{1} \mathrm{DU}_{1, \mathrm{t}-1}^{\prime}+\delta_{2} \mathrm{DU}_{2, \mathrm{t}-1}^{\prime}+\sum_{\mathrm{j}=1}^{\mathrm{k}} \beta_{\mathrm{j}} \Delta \mathrm{y}_{\mathrm{t}-\mathrm{j}}+\mathrm{e}_{\mathrm{t}} \\
\mathrm{y}_{\mathrm{t}}^{\mathrm{M} 2}=\rho_{\mathrm{t}-1}+\alpha^{*}+\beta^{*} \mathrm{t}+\Omega_{1} \mathrm{D}\left(\mathrm{T}_{\mathrm{B}}^{\prime}\right)_{1, \mathrm{t}}+\Omega_{2} \mathrm{D}\left(\mathrm{T}_{\mathrm{B}}^{\prime}\right)_{2, \mathrm{t}}+\delta_{1}^{*} \mathrm{DU}_{1, \mathrm{t}-1}^{\prime}+\delta_{2}^{*} \mathrm{DU}_{2, \mathrm{t}-1}^{\prime}+\gamma_{1}^{*} \mathrm{DT}_{1, \mathrm{t}-1}^{\prime} \\
+\gamma_{2}^{*} \mathrm{DT}_{2, \mathrm{t}-1}^{\prime} \sum_{\mathrm{j}=1}^{\mathrm{k}} \beta_{\mathrm{j}} \Delta \mathrm{y}_{\mathrm{t}-\mathrm{j}}+\mathrm{e}_{\mathrm{t}}
\end{gathered}
$$


The break dates are determined using a sequential procedure (see Narayan \& Popp, 2010) for the details of this procedure). The null hypothesis of a unit root of $\rho=1$ is tested against the alternative hypothesis of $\rho<1$, and t-statistics of $\hat{\rho}$ in Equations 3 and 4 are used. Critical values are generated through Monte Carlo simulations and depicted in Table 3 in Narayan and Popp (2010). If the calculated test statistics are greater than critical values, the null hypothesis of a unit root is rejected.

\subsection{Cointegration Tests}

Hatemi-J (2008) suggests a cointegration test considering structural breaks. Hatemi-J (2008) first considers the following equation:

$$
y_{t}=a+\beta^{\prime} x_{t}+u_{t}, t=1,2, \ldots, n
$$

This equation is generalized to take into account for the effects of two structural breaks on both the intercept and the slopes (two regime shifts) as follows:

$$
\mathrm{y}_{\mathrm{t}}=\alpha_{0}+\alpha_{1} \mathrm{D}_{1 \mathrm{t}}+\alpha_{2} \mathrm{D}_{2 \mathrm{t}}+\beta_{0}^{\prime} \mathrm{x}_{\mathrm{t}}+\beta_{1}^{\prime} \mathrm{D}_{1 \mathrm{t}} \mathrm{x}_{\mathrm{t}}+\beta_{2}^{\prime} \mathrm{D}_{2 \mathrm{t}} \mathrm{x}_{\mathrm{t}}+\mathrm{u}_{\mathrm{t}}
$$

Where D1t and D2t are dummy variables that are defined as

$$
\begin{aligned}
& D_{1 t}=\left\{\begin{array}{l}
0 \text { if } t \leq\left[n \tau_{1}\right] \\
1 \text { if } t>\left[n \tau_{1}\right]
\end{array}\right. \\
& D_{2 t}=\left\{\begin{array}{l}
0 \text { if } t \leq\left[n \tau_{2}\right] \\
1 \text { if } t>\left[n \tau_{2}\right]
\end{array}\right.
\end{aligned}
$$

with the unknown parameters $\tau_{1} \in(0,1)$ and $\tau_{2} \in(0,1)$, denoting the relative timing of the regime change point, and the bracket denotes the integer part. To test the null hypothesis of no cointegration, Hatemi-J (2008 uses the augmented Dickey-Fuller (ADF) test suggested by Engle and Granger (1987) and Z $\alpha$ and Zt tests developed by Phillips (1987). The ADF test is calculated by the corresponding t-test for the slope of $\hat{u}_{t-1}$ in a regression of $\Delta \hat{u}_{t}$ on $\hat{u}_{t-1}, \ldots, \Delta \hat{u}_{t-k}$, where $\hat{u}_{t}$ denotes the estimated error term from Eqn. (6). The $Z_{\alpha}$ and $Z_{t}$ test statistics are based on the calculation of the bias-corrected first-order serial correlation coefficient estimate $\hat{\rho}^{*}$, defined as

$$
\hat{\rho}^{*}=\frac{\sum_{\mathrm{t}=1}^{\mathrm{n}-1}\left(\widehat{\mathrm{u}}_{\mathrm{t}} \widehat{\mathrm{u}}_{\mathrm{t}+1}-\sum_{j=1}^{\mathrm{B}} \mathrm{w}(\mathrm{j} / \mathrm{B}) \widehat{\gamma}(\mathrm{j})\right)}{\sum_{\mathrm{t}=1}^{\mathrm{n}-1} \widehat{\mathrm{u}}_{\mathrm{t}}^{2}}
$$

where $\mathrm{w}($.$) is a function which provides kernel weights meeting the standard conditions for spectral density$ estimators, $\mathrm{B}$ is the bandwith number satisfying the conditions $\mathrm{B} \rightarrow \infty$ and $\mathrm{B} / \mathrm{n}^{5}=\mathrm{O}(1)$, and $\hat{\gamma}(\mathrm{j})$ is an autocovariance function. The autocovariance function is defined by

$$
\hat{\gamma}(j)=\frac{1}{n} \sum_{t=j+1}^{T}\left(\hat{u}_{t-j}-\hat{\rho} \hat{u}_{t-j-1}\right)\left(\hat{u}_{t}-\hat{\rho} \hat{u}_{t-1}\right)
$$

where $\hat{\rho}$ is the OLS estimate of the effect (without intercept) of $\hat{u}_{t-1}$ on $\hat{u}_{t}$. The $Z_{\alpha}$ and $Z_{t}$ test statistics are defined as follows:

$$
\mathrm{Z}_{\alpha}=\mathrm{n}\left(\hat{\rho}^{*}-1\right)
$$

and

$$
\mathrm{Z}_{\mathrm{t}}=\frac{\left(\hat{\rho}^{*}-1\right)}{\left(\widehat{\gamma}(0)+2 \sum_{\mathrm{j}=1}^{\mathrm{B}} \mathrm{w}(\mathrm{j} / \mathrm{B}) \widehat{\gamma}(\mathrm{j})\right) / \Sigma_{1}^{\mathrm{n}-1} \widehat{\mathrm{u}}_{\mathrm{t}}^{2}}
$$

where $\hat{\gamma}(0)+2 \sum_{\mathrm{j}=1}^{\mathrm{B}} \mathrm{w}(\mathrm{j} / \mathrm{B}) \hat{\gamma}(\mathrm{j})$ is the long-run variance estimate of the residuals of a regression of $\hat{\mathrm{u}}_{\mathrm{t}}$ on $\hat{\mathrm{u}}_{\mathrm{t}-1}$. These test statistics have nonstandard distributions, and Hatemi-J (2008) generates new critical values using Monte-Carlo simulations. The asymptotic distribution of the ADF test statistic is identical to the distribution of the $Z_{\mathrm{t}}$ statistics. Test statistics are the smallest values of these three tests across all values $\tau_{1}$ and $\tau_{2}$, with $\tau_{1} \in \mathrm{T} 1=(0.15,0.70)$ and $\tau_{2} \in \mathrm{T} 2=\left(0.15+\tau_{1}, 0.85\right)$. These test statistics are defined as follows:

$$
\begin{aligned}
\operatorname{ADF}^{*} & =\inf _{\left(\tau_{1}, \tau_{2}\right) \in \mathrm{T}} \operatorname{ADF}\left(\tau_{1}, \tau_{2}\right) \\
\mathrm{Z}_{\mathrm{t}}^{*} & =\inf _{\left(\tau_{1} \tau_{2}\right) \in \mathrm{T}} \mathrm{Z}_{\mathrm{t}}\left(\tau_{1}, \tau_{2}\right) \\
\mathrm{Z}_{\alpha}^{*} & =\inf _{\left(\tau_{1} \tau_{2}\right) \in \mathrm{T}} \mathrm{Z}_{\alpha}\left(\tau_{1}, \tau_{2}\right)
\end{aligned}
$$


where $T=(0.15 n, 0.85 n)$.

While the cointegration test developed by Hatemi-J (2008) considers two structural breaks, the relatively new cointegration test produced by Maki (2012) regards structural breaks until five different points for a sample.

According to the Maki (2012) cointegration test, every period in sampling period is a possible breaking point and $\mathrm{t}$-statistic for each period is computed. Then, periods with the lowest $\mathrm{t}$-statistics are specified as break points. Maki (2012) considers the following regression models to test for cointegration for multiple breaks:

$$
\begin{gathered}
\text { Model 0: } y_{t}=\mu+\sum_{i=1}^{k} \mu_{i} D_{i, t}+\beta^{\prime} x_{t}+u_{t} \\
\text { Model 1: } y_{t}=\mu+\sum_{i=1}^{k} \mu_{i} D_{i, t}+\beta^{\prime} x_{t}+\sum_{i=1}^{k} \beta_{i}^{\prime} x_{t} D_{i, t}+u_{t} \\
\text { Model 2: } y_{t}=\mu+\sum_{i=1}^{k} \mu_{i} D_{i, t}+\gamma t+\beta^{\prime} x_{t}+\sum_{i=1}^{k} \beta_{i}^{\prime} x_{t} D_{i, t}+u_{t} \\
\text { Model 3: } y_{t}=\mu+\sum_{i=1}^{k} \mu_{i} D_{i, t}+\gamma t+\sum_{i=1}^{k} \gamma_{i} D_{i, t}+\beta^{\prime} x_{t}+\sum_{i=1}^{k} \beta_{i}^{\prime} x_{t} D_{i, t}+u_{t}
\end{gathered}
$$

where $\mathrm{t}=1,2, \ldots, \mathrm{T}$. $\mathrm{y}_{\mathrm{t}}$ and $\mathrm{x}_{\mathrm{t}}=\left(\mathrm{x}_{1 \mathrm{t}}, \ldots, \mathrm{x}_{\mathrm{mt}}\right)^{\prime}$ denote observable $\mathrm{I}(1)$ variables, and $\mathrm{u}_{\mathrm{t}}$ is the equilibrium error. $\mathrm{y}_{\mathrm{t}}$ is a scalar, and $x_{t}=\left(x_{1 t}, \ldots, x_{m t}\right)^{\prime}$ is an $(m x 1)$ vector. Maki (2012) assumes that an $(n x 1)$ vector $z_{t}$ is generated by $\mathrm{z}_{\mathrm{t}}=\left(\mathrm{z}_{\mathrm{t}}, \mathrm{x}_{\mathrm{t}}^{\prime}\right)^{\prime}=\mathrm{z}_{\mathrm{t}-1}+\varepsilon_{\mathrm{t}}$, where $\varepsilon_{\mathrm{t}}$ are i.i.d. with mean zero, positive definite variance-covariance matrix $\Sigma$, and $\mathrm{E}\left|\varepsilon_{\mathrm{t}}\right|^{\mathrm{s}}<\infty$ for some s $>4 . \mu, \mu_{\mathrm{i}}, \gamma, \gamma_{\mathrm{i}}, \beta^{\prime}=\left(\beta_{1}, \ldots, \beta_{\mathrm{m}}\right)$, and $\beta_{\mathrm{i}}^{\prime}=\left(\beta_{\mathrm{i} 1}, \ldots, \beta_{\mathrm{im}}\right)$ are true parameters. $\mathrm{D}_{\mathrm{i}, \mathrm{t}}$ represents dummy variables and takes a value of 1 if $t>T_{B i}(i=1, \ldots, k)$ and of 0 otherwise, where $k$ is the maximum number of breaks and $\mathrm{T}_{\mathrm{Bi}}$ denotes the time period of break. Eqn. (14) has the model with level shifts. Eqn. (15) allows for structural breaks of level and regressors. Eqn. (16) extends model (1) with a trend. Eqn. (17) includes structural breaks of levels, trends, and regressors.

The critical values are generated through Monte Carlo simulation. If the calculated tests statistics are greater than critical values, the null hypothesis is rejected, and the rejection of the null hypothesis indicates a cointegration relationship among variables.

\subsection{Structural VAR Analysis}

Since the seminal paper of Sims (1980) arguing that vector autoregressive (VAR) models can forecast better than the structural equation models, VARs have been utilized in macroeconomics (Greene, 2003). An economist/policy maker/researcher who is only interested in forecasting might want to reduce the overparametrized VAR model to improve the accuracy of the estimates and reduce the forecast-error variance (Enders, 2015). Structural VAR (SVAR) approach serves for this goal.

SVAR approach can be explained through Amisano and Giannini (1997). In structural VAR analysis, the reduced form of a vector $\mathrm{y}_{\mathrm{t}}$ of economic variables is simply represented by a vector autoregression of the type:

$$
\begin{gathered}
\mathrm{A}(\mathrm{L}) \mathrm{y}_{\mathrm{t}}=\varepsilon_{\mathrm{t}} \\
\mathrm{A}(\mathrm{L})=\mathrm{I}-\mathrm{A}_{1} \mathrm{~L} \ldots \mathrm{A}_{\mathrm{p}} \mathrm{L}^{\mathrm{p}}
\end{gathered}
$$

and $\varepsilon_{\mathrm{t}}$ is a vector normal white noise with

$$
\mathrm{E}\left(\varepsilon_{\mathrm{t}} \varepsilon_{\mathrm{t}}{ }^{\prime}\right)=\Sigma
$$

For SVAR analysis, one needs to estimate of the parameters of an unrestricted reduced form

$$
\mathrm{A}(\mathrm{L}) \mathrm{y}_{\mathrm{t}}=\varepsilon_{\mathrm{t}}, \quad \mathrm{E}\left(\varepsilon_{\mathrm{t}} \varepsilon_{\mathrm{t}}{ }^{\prime}\right)=\Sigma
$$

obtaining estimates of $\mathrm{A}_{1} \ldots \mathrm{A}_{\mathrm{p}}$ as $\widehat{\mathrm{A}}_{1} \ldots \widehat{\mathrm{A}}_{\mathrm{p}}$

$$
\begin{aligned}
& \hat{\varepsilon}_{\mathrm{t}}=\widehat{A}(L) \mathrm{y}_{\mathrm{t}} \\
& \widehat{\Sigma}=\sum_{\mathrm{t}=1}^{\mathrm{T}} \frac{\hat{\varepsilon}_{\mathrm{t}} \hat{\varepsilon}_{\mathrm{t}^{\prime}}}{\mathrm{T}}
\end{aligned}
$$

In VAR analysis, the only source of the variation of $y_{t}$ variables are random shocks which are represented by a vector white noise $\varepsilon_{t}$. The vector of unobservable $\varepsilon_{t}$ variables is often called vector of innovations or vector of surprise variables.

Provided that $\mathrm{A}, \mathrm{e}$, and $\mathrm{B}$ are invertible matrices of order $\mathrm{n}$, the $\varepsilon_{\mathrm{t}}$ vector must fulfill the following conditions:

$$
\mathrm{A} \varepsilon_{\mathrm{t}}=\mathrm{Be}_{\mathrm{t}}
$$




$$
\begin{aligned}
& \mathrm{E}\left(\varepsilon_{\mathrm{t}}\right)=0 \\
& \mathrm{E}\left(\mathrm{e}_{\mathrm{t}} \mathrm{e}_{\mathrm{t}}{ }^{\prime}\right)=\mathrm{I}_{\mathrm{n}} \\
& \mathrm{A} \Sigma \mathrm{A}^{\prime}=\mathrm{BB}^{\prime}
\end{aligned}
$$

The vector of $e_{t}$ variables is a vector of orthonormal random variables and might be evaluated as independent unit variance random shocks of the corresponding $\mathrm{y}_{\mathrm{t}}$ variables. These independent unit variance random shocks can be regarded as the ultimate independent source of variation of the $\mathrm{y}_{\mathrm{t}}$ variables.

I employ SVAR analysis with short-run (contemporaneous) restrictions since i) monetary policy has a lagged effect on inflation as denoted previously and ii) Christiano et al. (2007) show that structural VARs perform so well when short-run restrictions are utilized for monetary transmission mechanisms.

Let me suppose a bivariate VAR model and so there are $\mathrm{n}^{2}=4$ parameters to be fixed. For such a VAR model, there will be $n(n+1) / 2=3$ restrictions, and so there will be $n(n-1) / 2=1$ free parameter. In accordance with the theory, I add a restriction so that the short-run response of inflation to a positive shock in real short-term interest rates is 0 .

\section{Estimation Results}

Table 2 depicts the results of ADF and PP unit root tests. Accordingly, both forms of both tests reveal that the test statistics for the first differences reject the null hypothesis and indicate that both series are stationary at first

\begin{tabular}{|c|c|c|c|c|c|}
\hline \multirow[t]{2}{*}{ Variable $^{\mathrm{a}}$} & & \multicolumn{2}{|c|}{ ADF test statistic } & \multicolumn{2}{|c|}{ PP test statistic } \\
\hline & & Intercept & Intercept and trend & Intercept & Intercept and trend \\
\hline INF & & -1.96 & -1.79 & -2.55 & -2.75 \\
\hline INT & & -1.34 & -1.20 & -1.33 & -1.32 \\
\hline$\Delta \mathrm{INF}$ & & $-8.44^{\mathrm{b}}$ & $-8.40^{\mathrm{b}}$ & $-6.65^{b}$ & $-7.46^{\mathrm{b}}$ \\
\hline$\Delta \mathrm{INT}$ & & $-6.40^{\mathrm{b}}$ & $-6.45^{\mathrm{b}}$ & $-6.40^{\mathrm{b}}$ & $-6.46^{\mathrm{b}}$ \\
\hline \multirow[t]{3}{*}{ Critical values } & $1 \%$ & -3.63 & -4.24 & -3.61 & -4.21 \\
\hline & $5 \%$ & -2.94 & -3.54 & -2.93 & -3.52 \\
\hline & $10 \%$ & -2.61 & -3.20 & -2.61 & -3.20 \\
\hline
\end{tabular}
differences. Then, the series are integrated of order 1, [I(1)].

Table 2. ADF and PP unit root tests

Note. ${ }^{\mathrm{a}} \Delta$ is the first difference operator. ${ }^{\mathrm{b}}$ Illustrates $1 \%$ statistical significance.

Table 3 reports the results of the Narayan and Popp (2010) unit root test. Accordingly, both variables are stationary at first differences since the test statistics for the first differences reject the null hypothesis of a unit root. Thus the series are integrated of order one with regard to all three tests.

Table 3. Narayan and Popp (2010) unit root test

\begin{tabular}{llcccc}
\hline Variable $^{\mathrm{a}}$ & \multicolumn{2}{c}{ Test statistic } & \multicolumn{2}{c}{ Break dates } & M2 \\
\cline { 3 - 5 } & & M1 & M2 & $2009: 1,2010: 4$ & $2008: 4,2010: 3$ \\
\hline INF & $-7.15^{\mathrm{c}}$ & -3.51 & $2008: 4,2011: 3$ & $2011: 3,2012: 2$ \\
$\mathrm{INT}$ & -3.22 & -1.20 & & \\
$\Delta \mathrm{INF}$ & & $-5.39^{\mathrm{c}}$ & $-5.58^{\mathrm{d}}$ & & \\
$\Delta \mathrm{INT}$ & & $-8.34^{\mathrm{c}}$ & $-6.02^{\mathrm{c}}$ & & \\
Critical values & $1 \%$ & -5.26 & -5.94 & & \\
& $5 \%$ & -4.51 & -5.18 & & \\
& $10 \%$ & -4.14 & -4.79 & & \\
\end{tabular}

Note. ${ }^{\mathrm{a}} \Delta$ is the first difference operator. ${ }^{\mathrm{b}}$ Critical values are obtained from Table 3 in Narayan and Popp (2010). ${ }^{\mathrm{c}}$ Illustrates $1 \%$ statistical significance. ${ }^{\mathrm{d}}$ Illustrates $5 \%$ statistical significance.

Table 4 shows the results of the Hatemi-J (2008) cointegration test. Accordingly, the null hypothesis of no cointegration can be rejected with regard to one of the three test statistics. 
Table 4. Hatemi-J (2008) cointegration test

\begin{tabular}{lccccc}
\hline \multirow{2}{*}{ Test statistic } & Estimated test value & \multicolumn{3}{c}{ Critical values $^{\mathrm{a}}$} & \multirow{2}{*}{ Break dates $^{2}$} \\
\cline { 3 - 5 } & & $1 \%$ & $5 \%$ & $10 \%$ & \\
\hline $\mathrm{ADF}^{*}$ & $-8.50^{\mathrm{b}}$ & -6.50 & -6.01 & -5.65 & $2009: 1,2009: 4$ \\
$\mathrm{Z}_{\mathrm{t}}^{*}$ & -4.42 & -6.50 & -6.01 & -5.65 & $2008: 1,2010: 1$ \\
$\mathrm{Z}_{\alpha}^{*}$ & -28.17 & -90.79 & -76.00 & -52.23 & \\
\hline
\end{tabular}

Note. ${ }^{\mathrm{a}}$ Critical values are obtained from Table 1 in Hatemi-J (2008). ${ }^{\mathrm{b}}$ Illustrates $1 \%$ statistical significance.

One may argue that additional findings are required to yield whether or not there is a cointegration relationship between variables. Therefore, Table 5 reports the results of the Maki (2012) cointegration test. As seen in Table 5, the test statistics for all models of the Maki (2012) cointegration test reject the null hypothesis of no cointegration. Therefore, one may argue that there is a cointegration relationship between INF and INT.

Table 5. Maki (2012) cointegration test ${ }^{\mathrm{a}}$

\begin{tabular}{lccccc}
\hline \multirow{2}{*}{ Model } & Test statistic & \multicolumn{3}{c}{ Critical values $^{\mathrm{b}}$} & \multirow{2}{*}{ Break dates } \\
\cline { 2 - 5 } & & $1 \%$ & $5 \%$ & $10 \%$ & \\
\hline 0 & $-7.64^{\mathrm{c}}$ & -5.56 & -5.08 & -4.78 & $2009: 22011: 4,2013: 3$ \\
1 & $-8.03^{\mathrm{c}}$ & -5.83 & -5.37 & -5.10 & $2009: 1,2011: 3,2014: 2$ \\
2 & $-7.84^{\mathrm{c}}$ & -6.25 & -5.70 & -5.40 & $2007: 1,2009: 2,2011: 4$ \\
3 & $-9.02^{\mathrm{c}}$ & -7.08 & -6.52 & -6.26 & $2009: 2,2011: 4,2013: 2$ \\
\hline
\end{tabular}

Notes ${ }^{\text {a }}$ The number of breaks is selected 3 due to the size of the sample. ${ }^{\mathrm{b}}$ Critical values are obtained from Table 1 in Maki (2012). ${ }^{\mathrm{c}}$ Illustrates $1 \%$ statistical significance.

Table 3, Table 4, and Table 5 also depict the estimated break dates in the Turkish economy. At first glance, it is seen that the breaking dates majorly correspond to the periods in the aftermath of the global financial crisis. Besides, beginning from 2008, there seem to be structural breaks in every year in Turkey.

The cointegration tests with structural breaks suggest that there is a cointegration relationship between INF and INT. In such a case, the estimation of SVAR models in levels provides consistent estimations (Berument et al., 2012). Thereby the monetary transmission lag in Turkey can be estimated through SVAR analysis using INF and INT in levels in the paper. Figure 2 shows the graphical presentations of impulse-response functions obtained from SVAR analysis.
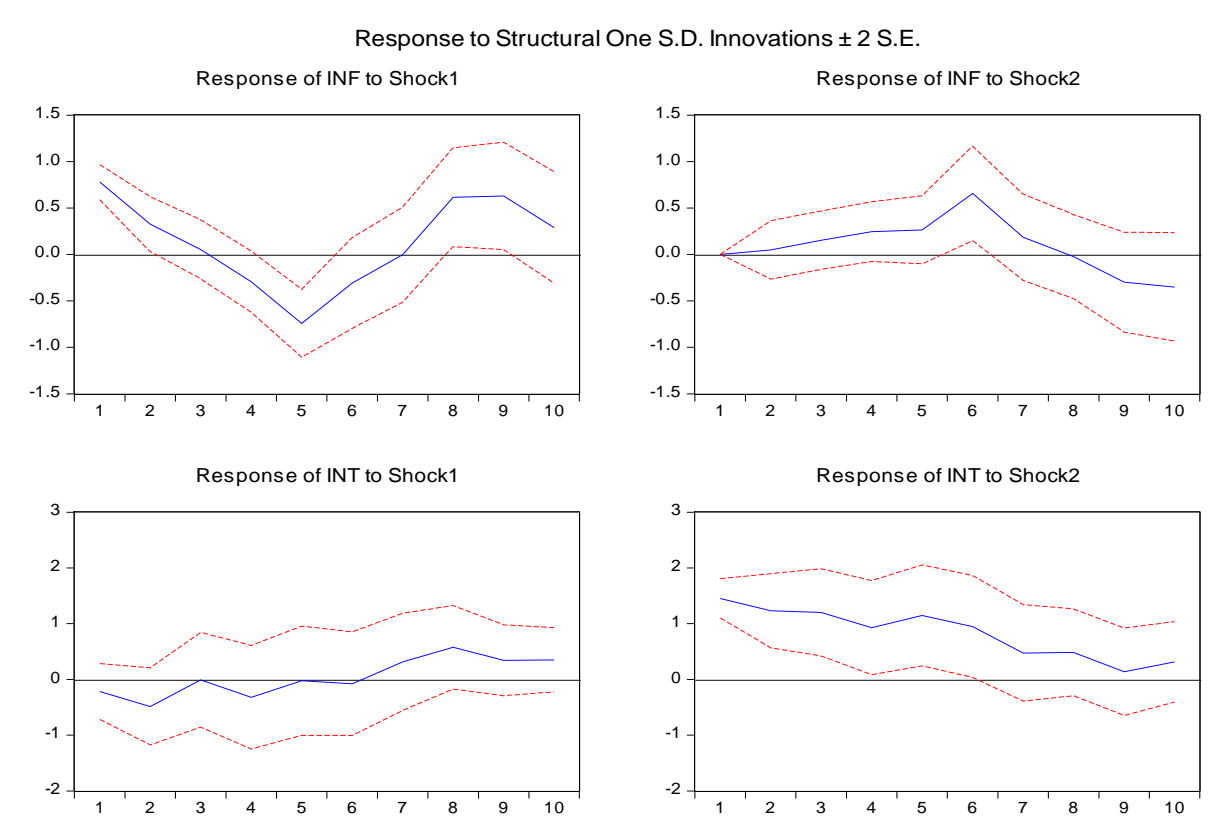

Figure 2. Graphical presentations of impulse-response functions obtained from SVAR analysis ${ }^{\mathrm{a}, \mathrm{b}}$

Note. ${ }^{\text {a }}$ The optimal lag length is 6 with regard to Akaike Information Criterion, and there are not autocorrelation and heteroscedasticity problems for this length. ${ }^{\mathrm{b}}$ I add break dates that the cointegration tests indicate to the SVAR models as an exogenous variable. 
The main event that Figure 2 portrays is the response of inflation rate to a positive one-unit standard deviation shock in real interest rate. As seen in Figure 2, a positive one-unit standard deviation shock to real interest rate induces inflation rate to rise in the first seven periods while the effect of the shock peaks in the sixth period. The expected decrease in inflation rate occurs only in the eighth period against a positive one-unit standard deviation shock to real interest rate. This negative effect prolongs up to the tenth period. When it is considered that this paper uses quarterly data for the empirical analyses, this paper yields that the monetary transmission lag for inflation is more than two years in Turkey. Because, SVAR analysis shows that the overall negative effect of a monetary policy action shows up in two and a half years in Turkey.

\section{Conclusion}

As a central that adopts inflation targeting strategy, the CBRT achieved inflation targets only in 2009 and 2010. Therefore, the reason why the CBRT misses inflation targets is considerable. As observed in Figure A, crude oil price that increased rapidly during January 2006-July 2008 decreased sharply because of the global financial crisis. Then, beginning from late 2008 , crude oil price increased rapidly in the world. Crude oil price has decreased since June 2014. Since crude oil price usually has a tendency to increase during the period 2006-2015, inflationary pressures increase in Turkey which is an oil importing country. Figure A also depicts the currency basket ((1 euro + 1 USD)/2), domestic currency per unit of foreign currencies, during the period 2006-2015. As seen, Turkish Lira depreciated markedly against foreign currencies in the same period. When one considers some recently produced papers yield in favor of exchange rate pass-through in Turkey (Arslaner et al., 2014; Choudhri \& Hakura, 2015; Cheikh \& Louhichi, 2016), he/she may argue that the depreciation of Turkish Lira has a role in missing inflation targets. Moreover, it may be argued that the depreciation of domestic currency in Turkey may have eliminated the positive effect of the decrease in crude oil price on inflation since mid-2014. Additionally, when consumer price index is examined by main expenditure groups, it is seen that prices of food and non-alcoholic beverages increased more quickly than most of the expenditure groups and thus than the consumer price index according to the Turkish Statistical Institute (2016) data. The fast increase in prices of food and non-alcoholic beverages is especially important since this group has the largest weight in consumer price index (23.68\%). Besides, even though alcoholic beverages and tobacco have a relatively low weight in consumer price index (4.98\%), the price of this group almost tripled during the period 2006-2015 especially because of the increase in taxes. Therefore, it might be argued that the rises in taxes on alcoholic beverages on tobacco increased inflation in Turkey.

This paper seeks additional findings about why the CBRT missed inflation targets. To this end, the paper estimates the monetary transmission lag in Turkey using quarterly data from 2006:1 to 2015:4. In other words, this paper examines when the overall effect of monetary policy on inflation is shown up after a monetary policy action in Turkey. Since consumption, investment, and saving decisions of economic actors depend on real interest rate, the paper uses real interest rate instead of nominal interest rate. After conducting ADF, PP, and Narayan and Popp (2010) unit root tests, this paper employs Hatemi-J (2008) and Maki (2012) cointegration tests with structural breaks. Then, it follows SVAR analysis to estimate the monetary transmission lag in Turkey. SVAR analysis yields that a positive one-unit standard deviation shock to real interest rate causes inflation rate to increase in the first seven periods. The decrease in inflation rate due to a positive one-unit standard deviation shock occurs only in the eighth period and this negative effect prolongs until the tenth period. When one considers that the paper employs quarterly data for the empirical analyses, he/she observes that the monetary transmission lag is more than two years in Turkey. Because, SVAR analysis indicates that the overall negative effect of a monetary policy action shows up in two and a half years in Turkey.

A recently developed and comprehensive paper by Havranek and Rusnak (2013) support the findings of this paper. They collect sixty-seven papers for thirty different economies to examine when prices bottom out after a monetary contraction and yield that the average transmission lag is twenty-nine months. Then, it may be argued it is not an expected event that the overall effect of a monetary policy action is shown up in more than two years. As denoted in Section 1, after Bulut (2016a) yields that the CBRT considers 12-month ahead expected inflation rate while it is steering interest rates, he suggest a question as follows: "Could the actual lag in monetary transmission mechanism be longer the estimation of the CBRT?" Starting from this point, this paper estimates the monetary transmission lag and finds that the lag in monetary transmission mechanism is two and a half years in Turkey. Therefore, this paper answers yes to the question above.

Hence this paper yields that monetary transmission lags may have a role in missing inflation targets in Turkey along with the increases in crude oil price, the depreciation of Turkish Lira, the increase in prices of food and non-alcoholic beverages, and the increase in alcoholic beverages and tobacco because of the increases in taxes on this group. In conclusion, the paper argues that the CBRT should pay attention to 24-month ahead or 
30-month ahead expected inflation rates instead of 12-month ahead expected inflation rate to achieve or run-up to inflation targets.

\section{References}

Amisano, G., \& Giannini, C. (2012). Topics in structural VAR econometrics (2nd ed.). Berlin: Springer.

Arslaner, F., Karaman, D., Arslaner, N., \& Kal, S. H. (2014). The Relationship between Inflation Targeting and Exchange Rate Pass-Through in Turkey with a Model Averaging Approach. CBRT Working Paper, 16, 1-54.

Artar, O. K. (2011). Türkiye'de para politikası kararlarının makroekonomik değişkenler üzerindeki etkisi: Vektör otoregresyon (VAR) analizi. The Journal of Marmara Social Research, 1, 1-17.

Basci, E., Ozel, O., \& Sarikaya, C. (2008). The monetary transmission mechanism in Turkey: New developments. BIS Papers, 35, 475-499.

Berument, H. M., Denaux, Z. S., \& Yalcin, Y. (2012). How does the exchange rate movement affect macroeconomic performance? A VAR analysis with sign restriction approach-evidence from Turkey. Economics Bulletin, 32(1), 295-305.

Berument, H., \& Malatyali, K. (2000). The implicit reaction function of the Central Bank of the Republic of Turkey. Applied Economics Letters, 7(7), 425-430. http://dx.doi.org/10.1080/135048500351104

Berument, H., \& Tasci, H. (2004). Monetary policy rules in practice: Evidence from Turkey. International Journal of Finance \& Economics, 9(1), 33-38. http://dx.doi.org/ 10.1002/ijfe.219

Bofinger, P., Reischle, J., \& Schächter, A. (2001). Monetary policy: Goals, institutions, strategies, and instruments. Oxford: Oxford University Press.

Brooks, P. K. (2007). The bank lending channel of monetary transmission: Does it work in Turkey? IMF Working Paper, 272, 1-11.

Bulut, U. (2016). How far ahead does the Central Bank of the Republic of Turkey Look? Journal of Central Banking Theory and Practice, 5(1), 99-111. http://dx.doi.org/10.1515/jcbtp-2016-0005

Central Bank of the Republic of Turkey. (2016). Retrieved from http://www.tcmb.gov.tr/

Cheikh, N. B., \& Louhichi, W. (2016). Revisiting the role of inflation environment in exchange rate pass-through: A panel threshold approach. Economic Modelling, 52, 233-238. http://dx.doi.org/10.1016/j.econmod.2014.11.004

Choudhri, E. U., \& Hakura, D. S. (2015). The exchange rate pass-through to import and export prices: The role of nominal rigidities and currency choice. Journal of International Money and Finance, 51, 1-25. http://dx.doi.org/10.1016/j.jimonfin.2014.09.006

Christiano, L. J., Eichenbaum, M., \& Vigfusson, R. (2007). Assessing structural VARs. In D. Acemoglu, K. Rogoff, \& M. Woodford (Eds.), NBER Macroeconomics Annual 2006 (1-106). Cambridge: MIT Press.

Cicek, M. (2005). Türkiye'de parasal aktarım mekanizması: VAR (vektör otoregrasyon) yaklaşımıyla bir analiz. Iktisat Isletme ve Finans, 20(233), 82-105.

Clarida, R., Gali, J. \& Gertler, M. (1998). Monetary policy rules in practice: Some international evidence. European Economic Review, 42(6), 1033-1067. http://dx.doi.org/10.1016/S0014-2921(98)00016-6

Clarida, R., Gali, J., \& Gertler, M. (2000). Monetary policy rules and macroeconomic stability: Evidence and some theory. The Quarterly Journal of Economics, 115(1), 147-180. http://dx.doi.org/10.1162/00335530055469

Dickey, D. A., \& Fuller, W. A. (1981). Likelihood ratio statistics for autoregressive time series with a unit root. Econometrica, 49(4), 1057-1072. http://dx.doi.org/10.2307/1912517

Enders, W. (2015). Applied econometric time series (4th ed.). USA: John Wiley \& Sons.

Energy Information Administration. (2016). Retrieved from https://www.eia.gov/

Engle, R. F., \& Granger, C. W. (1987). Co-integration and error correction: Representation, estimation, and testing. Econometrica, 55(2), 251-276. http://dx.doi.org/10.2307/1913236

Erdogan, S., \& Besballi, S. G. (2011). Türkiye'de banka kredileri kanalının işleyişi üzerine ampirik bir analiz. Doguş Universitesi Dergisi, 11(1), 28-41.

Friedman, M. (1961). The lag in effect of monetary policy. The Journal of Political Economy, 69(5), 447-466. 
Friedman, M. (1968). The role of monetary policy. The American Economic Review, 58(1), 1-17.

Friedman, M. (1972). Have monetary policies failed? The American Economic Review, 62(1/2), 11-18.

Goodhart, C. A. (2001). Monetary transmission lags and the formulation of the policy decision on interest rates. Federal Reserve Bank of St. Louis Review, 83(4), 165-182.

Greene, W. H. (2003). Econometric analysis (5th ed.). USA: Pearson Education.

Guloglu, B., \& Orhan, S. (2008). Türkiye'de parasal aktarım mekanizmalarının makroekonomik etkileri. Iktisat Isletme ve Finans, 23(268), 94-118.

Hatemi, J. A. (2008). Tests for cointegration with two unknown regime shifts with an application to financial market integration. Empirical Economics, 35(3), 497-505. http://dx.doi.org/10.1007/s00181-007-0175-9

Havranek, T., \& Rusnak, M. (2012). Transmission lags of monetary policy: A meta-analysis. International Journal of Central Banking, 9(4), 39-75.

Judd, J. P., \& Rudebusch, G. D. (1998). Taylor's Rule and the Fed: 1970-1997. Economic Review-Federal Reserve Bank of San Francisco, 3, 3-16.

Kara, A. H. (2012). Turkish experience with implicit inflation targeting. Central Bank Review, 8(1), 1-16.

Maki, D. (2012). Tests for cointegration allowing for an unknown number of breaks. Economic Modelling, 29(5), 2011-2015. http://dx.doi.org/10.1016/j.econmod.2012.04.022

Mishkin, F. S. (2012). Macroeconomics: Policy and practice. USA: The Addison-Wesley Series in Economics.

Narayan, P. K., \& Popp, S. (2010). A new unit root test with two structural breaks in level and slope at unknown time. Journal of Applied Statistics, 37(9), 1425-1438. http://dx.doi.org/10.1080/02664760903039883

Ornek, I. (2009). Türkiye'de parasal aktarım mekanizması kanallarının işleyişi. Maliye Dergisi, 156, 104-125.

Phillips, P. C. (1987). Time series regression with a unit root. Econometrica, 55(2), 277-301. http://dx.doi.org/10.2307/1913237

Phillips, P. C., \& Perron, P. (1988). Testing for a unit root in time series regression. Biometrika, 75(2), 335-346. http://dx.doi.org/10.1093/biomet/75.2.335

Sims, C. A. (1980). Macroeconomics and reality. Econometrica, 48(1), 1-48.

The Banks Association of Turkey. (2016). Retrieved from https://www.tbb.org.tr/tr

Turkish Statistical Institute. (2016). Retrieved from http://www.tuik.gov.tr/Start.do

Yazgan, M. E., \& Yilmazkuday, H. (2007). Monetary policy rules in practice: Evidence from Turkey and Israel. Applied Financial Economics, 17(1), 1-8. http://dx.doi.org/10.1080/09603100600606206

Note

Note 1. The monetary policy strategy that the CBRT adopted between 2002-2005 is denominated as "implicit inflation targeting". Under this strategy, the CBRT not only used short-term interest rate to achieve inflation targets but also tried to achieve the target for monetary base. See Kara (2012) for details of the implicit inflation targeting in Turkey.

\section{Appendix}

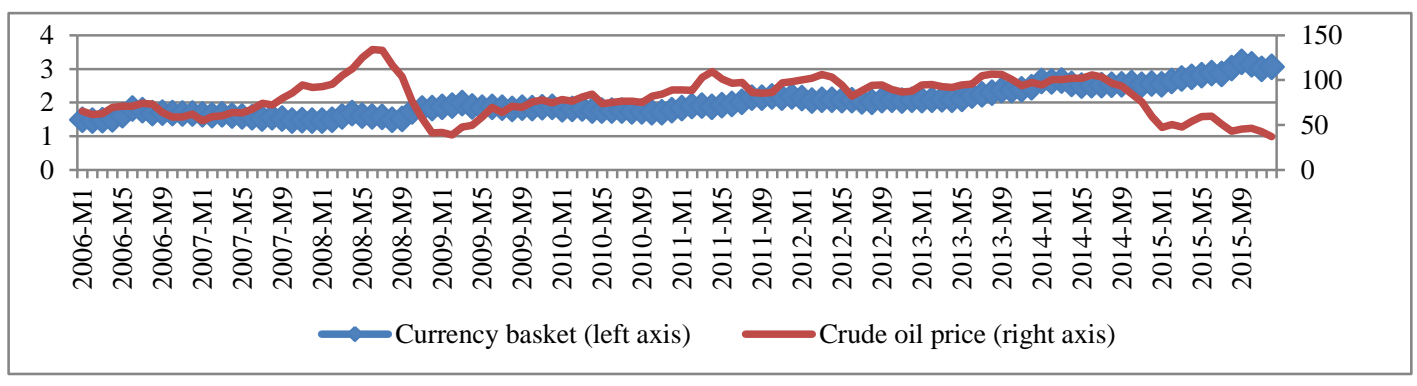

Figure A. Crude oil price in the world economy and currency basket in Turkey

Source: CBRT (2016) and Energy Information Administration (2016). 


\section{Copyrights}

Copyright for this article is retained by the author(s), with first publication rights granted to the journal.

This is an open-access article distributed under the terms and conditions of the Creative Commons Attribution license (http://creativecommons.org/licenses/by/3.0/). 